\title{
AN ANALYSIS OF STUDENTS' ABILITY IN CONSTRUCTING INFORMATION QUESTION
}

\author{
Destiantari Adila, Aryuliva Adnan, Fitrawati \\ English Department \\ Faculty of Languages and Arts \\ State University of Padang \\ Email : destiantariadila@yahoo.co.id
}

\begin{abstract}
Constructing information question with correct grammar is an ability that should be owned by the students. The aim of this research is to find out the research question about how the students' ability in constructing information question is. This is a descriptive research. The data were collected from twenty-eight students of eighth grade of SMP 30 Padang that were chosen randomly. This research used test as the instrument that consist of twelve question tests that represent question word what, where, who, why, when, and how. Analysis data based on indicators of information question; question word, auxiliary verb, subject, main verb, and sentence complement. From the result of this study, it was gained that students' abilities were very good in determining question word, not very good in determining auxiliary verb, good in determining subject, not good in determining verb, and average in determining complement. It can be concluded that students have good ability in determining question word, subject, and complement in constructing information question, while students still have low ability in determining auxiliary verb and verb in constructing information question.
\end{abstract}

Keywords: Question, Information Question, Question Word.

Abstrak: Kemampuan bertanya dalam belajar Bahasa Inggris adalah kemampuan yang harus dimiliki siswa. Kemampuan bertanya yang dimiliki juga harus sesuai dengan tata bahasa yang benar. Penelitian ini dimaksudkan untuk menjawab pertanyaan penelitian bagaimana kemampuan siswa membuat pertanyaan informasi. Penelitian ini digolongkan kedalam penelitian deskriptif. Data dikumpulkan dari 28 siswa kelas VIII SMP 30 Padang yang dipilih secara acak. Penelitian ini dikumpulkan dengan menggunakan instrument berupa test yang terdiri dari dua belas butir soal yang mewakili kata tanya what, where, who, why, when, dan how. Data dianalisis berdasarkan indikator pertanyaan informasi question word (kata tanya), auxiliary verb (kata bantu), subject (subjek), main verb (kata kerja), dan sentence complement (kalimat pelengkap). Dari hasil penelitian didapatkan bahwa kemampuan siswa dalam menentukan kata tanya adalah sangat baik, kemampuan siswa dalam menentukan kata bantu adalah sangat tidak baik, kemampuan siswa dalam menentukan subjek adalah baik, kemampuan siswa dalam menentukan kata kerja adalah tidak baik, kemampuan siswa dalam menentukan kalimat pelengkap adalah rata-rata. Dapat disimpulkan bahwa siswa memiliki kemampuan yang baik dalam menentukan kata tanya, subjek, dan kalimat pelengkap dalam membuat pertanyaan informasi, sedangkan siswa masih memiliki kemampuan yang rendah dalam menentukan kata bantu dan kata kerja dalam membuat pertanyaan informasi.

Kata Kunci: Pertanyaan, Pertanyaan Informasi, Kata Tanya. 


\section{INTRODUCTION}

Since English has important role in human's life, it is learned to be mastered by users of English as foreign and second language. In Indonesia where English still become a foreign language, it is taught at school such as junior and senior high school and become a compulsory subject to be learned by students. Students of junior and senior high school who want to graduate from the school should reach the standardized score of English test. So, the students are demanded to master English.

Question is one of grammar lesson that should be learned by the students begun from junior high school. According to Flachmann (2011), question is one type of sentence that has subjected and predicate at least where it will be a message to communicate. It becomes compulsory subject for the students to understand other English skill such as listening, speaking, reading, and writing. To create a communicative classroom, students are demanded to understand how to construct question.

There are some definitions of expert about question or interrogative sentence. A question is always followed by a question mark and a part of the verb always comes before the subject. Quirk (1973) adds that questions are sentence marked that have three criteria. They are place of operator immediately in front of the subject, the initial positioning of an interrogative, and rising intonation.

According to Leech (2006), question is a type of sentences or clauses which has an information gap. The information gap is the time when the stated event occurred. $\mathrm{He}$ adds that it is typically interpreted as requesting information from another person. It is a linguistic expression used to make a request for information or the request made using such an expression. The request is asked based on the questioner's need.

According to Byrd and Benson (2001), questions are important parts for students and teachers. Students ask questions to the teachers and conversely. Students will answer questions in test given by the teacher. So, good understanding about question is crucial for students to learn and for teacher to teach. Question is useful in classroom to appear communication.

Communication happens when there is conversation between students and teacher. The conversation is begun by asking question. Bibber (2002) says that questions reflect the nature interactive of conversation. So, in classroom it is essential to achieve the goal of the learning. Sockalingam (2011) adds that questioning is essential in good teaching. It is also to ensure that students are attentive and engaged, and to assess students' understanding.

Good learning starts with questions, not answer. Questioning will enable teachers to check learners' understanding. It also helps learners engage and focuses their thinking on key concepts and ideas. Moreover, Friedman (2004) says that it helps teacher completely understand the students' situation, responding to what teacher guess 
the students' means, which may or may not be correct.

Questions are significant subject learnt by the students. Students will ask question to the teacher and answer teacher's question in class and on test. Asking the right question is at the main point of effective communications and information exchange. According to Pesacreta (2011) answering question is a fundamental component to educational and social development. Students are demanded to know and understand about the questions.

Based on preliminary research, students face some problems in mastering the questions. First, they get difficulty in making distinction of the kind of questions such as yes/no question or information question.

In the information question, students have to know question words in asking questions. They are what, when, where, why, who, whom, whose, which and how. Some of the students still do not understand the question words. It is proved when students answer reading text question; they cannot answer the question well. For example the question is about place while they answer with time because they cannot differentiate between where and when.

The students also get difficulties in answering teacher's questions because they still do not understand the function of the question words in information question. On the other hand, In yes/no question, to be such as is, am, are and modal auxiliary such as will, can, may, etc. are used as the question word.
The students are confused what kind of to be and modal auxiliaries are used in the question sentence. Answering for yes/no question must be yes or no as the question type but the fact show that there is mistake made by the students.

Second, constructing a question is rather difficult by the students. In constructing a question, students should know the correct grammar. They should identify what kind of question should be created based on the information that is expected to get. They also should identify the right tenses.

Making information question is rather difficult than yes/no question. They have to understand yes/no question first before understanding information question. Whereas, students will get more information in class if they are able to ask in information question or respond the questions.

Most of the students did not understand the pattern of the question. In a question sentence, there should be some aspect such as question word, subject, auxiliary verb, verb, or complement where they should be arranged based on right pattern in order to be a good question sentence. The students cannot understand perhaps because of the influence of their L1 (Indonesian) with their L2 (English). There are different patterns between both languages in constructing question.

According to Byrd (2001), in forming an information question, students can follow some steps. First, students can add the correct question word and put it at the 
beginning of the question. Second, the form of be is added in front of the subject.

If there is no form of be, students can use the correct form of $d o$ and then the sentence's verb is changed to its simple form (this step is used only for simple present tense or simple past tense forms). Finally, the sentence is finished by adding the question mark at the end of it.
In addition, Claudio (2006) formulates a method to construct question that is called 1-2-3-4-5 format. This format arranges questions (yes no question and information question) in any verb tense into a sequence of number. A number (1-5) is assigned to one particular syntactic structure in the following order.

Table 1: 1-2-3-4-5 format

\begin{tabular}{|c|c|c|c|c|}
\hline $\mathbf{1}$ & $\mathbf{2}$ & $\mathbf{3}$ & $\mathbf{4}$ & $\mathbf{5}$ \\
\hline $\begin{array}{c}\text { Information } \\
\text { Question expression }\end{array}$ & $\begin{array}{c}\text { Yes No } \\
\text { Question } \\
\text { expression }\end{array}$ & $\begin{array}{c}\text { Subject of the } \\
\text { sentence (noun } \\
\text { phrase) }\end{array}$ & $\begin{array}{c}\text { Main verb } \\
\text { (verb phrase) }\end{array}$ & $\begin{array}{c}\text { Sentence } \\
\text { Complement }\end{array}$ \\
\hline
\end{tabular}

Thus, analyzing students' ability in constructing information question seen by the question word, auxiliary verb, subject, main verb, and sentence complement was the purpose of the study.

\section{METHOD}

This study was a descriptive research. Through descriptive research, an event that becomes attention without giving special treatment to the event can be described. According to Gall (2007), descriptive research involves describing characteristic of a particular sample of individuals or other phenomena.

Gay (2009) adds that a descriptive research involves collecting data in order to test hypothesis or to answer questions concerning the current status of the subject of the study. Moreover, it determines and reports the way things are as the representative about current condition. Thus, it was used in this research to describe students' ability in constructing information questions.

The population of the research was the eighth grade students of SMP 30 Padang registered on 2013/2014 academic year. The eighth grade was chosen because the problem was found when the students learned about the information questions in the eighth grade. Sample of this research was chosen among the eighth grade by using random sampling.

The instrument of this research was a test. The test consists of twelve number that represent six question words (what, why, where, when, who, and how). Question number 1 and 2 were for question word what. Question number 3 and 4 were for question word where. Question number 5 and 6 were for question word who. Question number 7 and 8 were for question word why. Question number 9 and 10 were for question word when. Question number 11 and 12 were for question word how. There 
is a situation of each number in the test. The students read the situation of each number to construct information question.

The data of this research were collected from students' test. The data were analyzed in order to get information. The data were scored by the researcher. The data were scored based on indicators below:

a. The question word b. The auxiliary verb

c. Subject / personal pronoun

d. Main verb

e. Compliment

In order to get the description of each type of students' ability, the result will be classified into the following interval as suggested by Harris (1969) that will be adapted for this research.

Table 2: The Classification of Students' Ability

\begin{tabular}{|c|c|}
\hline Interval Percentage & Classification \\
\hline $81-100$ & Excellent \\
\hline $66-80$ & Good \\
\hline $56-65$ & Average \\
\hline $41-55$ & Poor \\
\hline $0-40$ & Very poor \\
\hline
\end{tabular}

After tabulating the data, the result of data analysis were described to answer the research problems.
FINDING AND DISCUSSION

Students' ability in constructing information question could be classified based on question's indicators; question word, auxiliary verb, subject, verb, and complement.

Table 3: Students' Ability Seen by Five Question Indicator

\begin{tabular}{|c|c|c|c|c|c|}
\hline Test & Question word & $\begin{array}{c}\text { Auxiliary } \\
\text { verb }\end{array}$ & Subject & Verb & Complement \\
\hline 1 & 28 & 23 & 28 & 0 & 0 \\
\hline 2 & 28 & 2 & 28 & 3 & 19 \\
\hline 3 & 26 & 1 & 28 & 10 & 27 \\
\hline 4 & 27 & 0 & 1 & 0 & 0 \\
\hline 5 & 27 & 18 & 10 & 0 & 0 \\
\hline 6 & 26 & 20 & 22 & 0 & 0 \\
\hline 7 & 26 & 0 & 25 & 0 & 12 \\
\hline 8 & 26 & 15 & 28 & 28 & 15 \\
\hline 9 & 28 & 6 & 26 & 15 & 27 \\
\hline 10 & 24 & 0 & 22 & 0 & 21 \\
\hline 11 & 14 & 2 & 25 & 4 & 7 \\
\hline 12 & 12 & 12 & 19 & 0 & 0 \\
\hline
\end{tabular}




\begin{tabular}{|c|c|c|c|c|c|}
\hline Total & $\mathbf{2 9 2}$ & $\mathbf{9 9}$ & $\mathbf{2 6 2}$ & $\mathbf{6 0}$ & $\mathbf{1 2 8}$ \\
\hline $\boldsymbol{\%}$ & $\mathbf{8 7 \%}$ & $\mathbf{2 9 \%}$ & $\mathbf{7 8 \%}$ & $\mathbf{4 3 \%}$ & $\mathbf{6 5 \%}$ \\
\hline
\end{tabular}

Based on the data found, there were some problems identified of students in constructing information question. First, the problems found from the first indicator of question, it is question word. Almost all students answered correctly in determining the question word. Unfortunately, still there were some students could not determine the question word well such as how, why, where, when and who (Test number 3, 4, 5, $6,7,10,11$, and 12). It could happen because the students use the question rarely while the fact they knew the meaning of the question word used.

Based on the data, there was no student that had mistake in constructing question with question word what because they often used that question. For some students, they did not pay attention to the instruction with situation given, so that they constructed the question with wrong question word.

Second, mistakes made by the students from question indicator auxiliary verb. Almost all students have mistakes in determining the auxiliary verb (table 3 ). Even, there are three items that nobody could answer them. Thus, there were three problems the students had in determining the auxiliary verb in constructing information question. First, students had problem in verbal sentence. Students should use auxiliary verb do, does, and did in verbal sentence.

Meanwhile the use of the auxiliary depends on the subject and the tenses.
Second, students had problem in nominal sentence. Many of the students did not use appropriate to be in nominal sentence such as $i s$, are, am, was, and were where the use of to be also depends on the subject and the tenses. Third, students got problems in determining the tenses. There were two tenses the students learned in the eighth grade; they were simple present and simple past tense.

The use of the auxiliary verb depends on the subject and tenses. For nominal sentence, is, am, and are used in simple present tense and was and were, are used in simple past tense. For verbal sentence, do and does are used in simple present tense and $d i d$ is used in simple past tense.

Third, in determining the subject, students should know that subject could be noun, pronoun or possessive. Based on table 3 , there was one item that only one student answered correctly. In a question, subject is always placed after auxiliary verb. There are $22 \%$ of the students made mistake in determining the place of the subject.

Fourth, there is a problem that students face in determining verb in constructing question. Verb will change depending on the tenses. Verb changing in simple past tense should be paid attention by the students. Almost all students got problem in verb changing in this simple past tense. Based on the rule, verb in past tense will change become past form for positive 
sentence. In interrogative and negative sentence or question, the verb will change to base form, because there had auxiliary did in replacing it.

Fifth, the main problem of students in determining the sentence complement is the students do not know the vocabulary used in the questions. The most problem was in question number 11 that just seven students answered the sentence complement correctly. Overall, just few students made mistakes.

Based on the table 3 and explanation above that students' ability in constructing information question could be seen from the five indicators. First, in determining the question word, $87 \%$ students answered the question word correctly. It means the students have excellent ability in determining the question word. Second, in determining the auxiliary verb, 29\% students answered auxiliary verb correctly.

It means the students' ability is still very poor in determining it. Third, students' ability in determining the subject is good as the data showed $78 \%$ students answered subject correctly. Fourth, 43\% students answered verb correctly in determining the verb which means their ability still poor. Finally, in constructing the sentence complement, students have average ability as the data $65 \%$ students answered correct sentence complement.

All students of the eighth grade have studied about information question. Some of them have good ability because they understand of what the instruction given and they could construct the question as expected although they still have mistake on the sentences. It is believed that they often use the question in dialog or conversation, so that they can construct the question easily.

Students that have average ability are not so careful in reading the instruction given and constructing the question. And students that have poor ability are believed that they cannot construct the question because they do not know the pattern of an information question although they have learned about it. It is also believed that they did not pay attention to the teacher's explanation about it before.

According to Claudio (2006) the five indicators in question should be mastered to construct appropriate question, they are question word, auxiliary verb, main verb, subject, and complement. Students should understand to each indicator in order to construct question well.

\section{CONCLUSION}

Based on the research findings, it can be concluded that first, the eighth grade students of SMP 30 Padang had excellent ability in determining the question word in constructing information question. Second, the students had very poor ability in determining the auxiliary verb. Third, the students had good ability in determining the subject. Fourth, the students had poor ability in determining the verb. And fifth, the students had average ability in determining the complement. So, the students have been able to construct information question in terms of determining the question word, subject, and 
complement, meanwhile the students still have low ability in determining the auxiliary verb and the verb.

There are some aspects that limit this research. First, the time of taking the data was not conducive because it was taken after the students having final semester examination. It made them not to concentrate answering the test. Second, the students were not taught about information question in specific time. It means they did not learn about information question specifically that made them not so understand in constructing information question. Third, some students cheated their friend when answer the test given. There are some similar answers made by the students because of cheating each other.

\section{REFERENCES}

Biber, Douglas, et al. (2002). Student Grammar of spoken and written English. Edinburgh: Pearson Education.

Byrd, Patricia and B. Benson. (2001). Applied English Grammar. Boston: Thomson Leaming Inc.

Claudio, A. Munoz. (2006). 1-2-3-4-5 An Easy Way to Make Question in English (yes / no \& information question). Retrieved from http://wwwl.uprh.edu on May 15 $5^{\text {th }}, 2013$.

Flachmann, Kim. (2011). Mosaics: Reading and writing Essays. Bakersfield: Pearson Education Inc.

Friedman, Nancy. (2004). Effective Questioning Skill. Retrieved from http://www.connections magazine.com on April 18 $8^{\text {th }}, 2012$.

Gall, Meredith D, Joyce P. Gall, and Walter R. Borg. (2007). Educational Research. Boston: Pearson Education Inc.

Gay, L.R. (2009). Educational Research: Competencies for Analysis and Application. New Jersey: Pearson Education.

Harris, David P. (1969). Testing English as a Second Language. New Delhi: Mc Graw Hill Publishing Company.

Leech, Geoffrey. (2006). A Glossary of English Grammar. Edinburgh: Edinburgh University Press.

Pesacreta, Mara. (2011). How to Improve My Ability to Answer Question. Retrieved from http://www.ehow.com on April 18 $18^{\text {th }}, 2012$.

Quirk, Randolph. (1973). A university Grammar of English. Harlow: Longman.

Sockalingam, Nachamma. (2011). Questioning skill to engage students. Retrieved from http:/l www.facultyfocus.com on April 18, 2013. 